\title{
UNINTENTIONAL HOMICIDE IN THE COMMISSION OF AN UNLAWFUL ACT
}

\section{WILNER $\dagger$}

\section{HistoricaI}

Bracton, while asserting that one who commits homicide by chance, as by misfortune, is not liable to punishment for "homicide", very interestingly adds "But here it is to be distinguished whether a person is employed upon a lawful or unlawful work, as if a person has projected a stone towards a place across which men are accustomed to pass, or whilst a person pursues a horse or an $o x$, and someone has been struck by the horse or the ox, and such like, this is imputed to his account. But if he was employed in a lawful work, as if a master is flogging his scholar for the sake of discipline, or if when a person was casting down hay from a cart . . . if he had taken as diligent care as he could, by looking out and by calling out .. . in suitable time and with a loud voice . . . blame is not imputable to him." 1 (Italics supplied.)

Whether this passage actually represents the law as it existed in Bracton's time or not (significance can be attached to the fact that this concept of unlawful act is not noted at all by Glanville or Britton who wrote at approximately the same time as Bracton), it is quoted as the first clear statement on the subject to be found in English law. As it stands, this passage is already full of the uncertainties and doubts which have pervaded this subject for centuries since. Expressed in modern terms, this passage contains the proposition that an unintentional homicide can under no circumstances be held to be a case of misadventure unless it happened in the commission of a lawful act, while proper care to avoid injury was being taken by the defendant. It is to be noted that the standard of care required by Bracton is a subjective one. The defendant must have taken as diligent care as he could, not merely reasonable'care. Bracton does not specify the kind of unlawfulness which, if present, will cause the homicide to be "imputed to his account", nor what the consequences of the guilt, if imputed, are. It is to be noted, however, that the examples mentioned by Bracton are distinguished by wilful action in the face of manifest danger to human safety. The meaning attached to "unlawful act" in the subsequent development of the law, therefore, becomes the subject of further inquiry.

† B. A., 1932, Clark University; LL. B., 1935, LL. M., 1936, University of Pennsylvania; member of the Pennsylvania bar.

I. DE LEGBUS, Liber III, ad treatise, c. 4 . 
Coke stated the rule that if the homicide occurred while the defendant was engaged in the commission of an unlawful act, it was murder. While this author stated the consequences of such homicide in a more specific manner, he did not make it clear what kind of unlawful act will make the homicide murder. From the illustration which he furnished in connection with his rule, it is clear that he held it to be the law that any unlawful act, even if not a felony, was sufficient. ${ }^{2}$ The difference between shooting at a tame fowl, and at a fowl fera nature, which is not a subject of larceny, was the decisive factor in determining whether a man who happened to kill somebody by the glancing of his arrow was to be condemned as a murderer, or his case adjudged to be one of misfortune and misadventure. Hale represents an advance in the law by narrowing the scope of the "unlawful act" which will prevent a homicide happening in its commission from being per infortunium. To him, also, a homicide is purely "involuntary" and casual where a man is doing a laweful act, and without intention of bodily harm to any person, "as if a man be shooting at buts or pricks, and by casualty his hand shakes, and the arrow kills a by-stander". ${ }^{3}$ However, by his statement that malice will be implied when a homicide is committed by a person while intending theft or burglary, ${ }^{4}$ he in effect says that at least where the unlawful act is not a felony, the homicide will not be deemed murder but merely manslaughter. A new refinement was introduced by Hawkins and Foster. Both of these authors place a good deal of emphasis on the intention of doing "mischief", though not making it clear just what kind of conduct may be labeled mischievous. ${ }^{5}$ Certain it is that a felony, even if it were merely an attempt to steal a deer, was regarded as mischief per se. ${ }^{6}$ In the case of Rex $v$. Keate, ${ }^{7}$ Chief Justice Holt expressed the opinion that Coke's statement above referred to, was a very exaggerated proposition of law, and that such unintentional homicide would amount to murder only where there was

2. 3 Co. INST. ${ }^{*} 56$. For an early example of homicide which was not considered a felony because unintentionally caused in the commission of a lawful act, see I5 VINER, A Generat ABridgment of LAW AND EQUTTY (2d ed. 1793) 5I0: "If I cut my tree and the branch falls upon a man, and kills him against my will, this is not felony. . . ." J. Kelyng cites PouLtoN, DE PACE 120, that it is but misadventure if there was warning given, Kel. J. 40. So also "if a man shoots at butts, and his arrow glances, and he kills a man, this is not felony. . . " VINER, loc cit. supra.

3. I Hale, Pleas of the Crown *472.

4. Id. at * 455 .

5. "That which is without malice is called manslaughter, or sometimes chancemedley, by which we understand such killing as happens either on a sudden quarrel, or in the commission of an unlawful act, without any deliberate intention of doing any mischief at all." I HAwkINS, PleAs of THE CROWN (6th ed. Leach, I788) II5. "If an action unlawful in itself be done deliberately and with intention of mischief or great bodily harm . . fall it where it may, and death ensues against or beside the original intention of the party, it will be murder." (Italics supplied.) FosTeR, CROWN CASES ( $3 \mathrm{~d}$ ed. I792) 261 .

6. Id. at 259 .

7. Comb. 406 (K. B. I697). 
(a) an intent to commit any felony, or (b) a design of mischief toward a person. ${ }^{8}$ In Rex $v$. Plumer, ${ }^{9}$ Chief Justice Holt reiterated the above opinion, and said that where the defendant was committing or intending to commit a felony, the unintentional homicide will be murder even if the felony did not tend to hurt anybody. If not done in the commission of a felony, the homicide will be murder if the unlawful act be a deliberate one, and mediately or immediately tending to hurt someone; otherwise it will be manslaughter. Blackstone, likewise, considered the likelihood of doing bodily mischief to another person as the factor which determines when an unlawful act is of the quality required to make the unintentional homicide resulting from its commission murder or merely manslaughter. ${ }^{10}$ For the homicide to be manslaughter, it is tacitly assumed in all the sources referred to, that it is irrelevant whether there was any intention of doing mischief or not. The later English cases have not altered this view. In the case of Regina $v$. Packard, ${ }^{11}$ the facts were that $D$, in order to prevent a deputy-sheriff from consummating a levy upon his property, got the latter to drink heavily, no compulsion or any slighter pressure having been resorted to by $D$. After the deputy-sheriff became intoxicated, he was put in a carriage by $D$ and driven around for several hours. The deputy-sheriff died of the combined effects of the liquor and the bumps to which he was subjected by the moving of the carriage. It was held that $D$ was guilty of manslaughter because $D$ 's purpose to get his property out of the possession of the victim rendered his drinking with the sheriff, and driving him about, unlawful acts. The lack of intent to cause death or any harm, or the absence of reasonable expectation of the result, did not weight the scale in $D$ 's favor.

\section{The Justification for the Rule that the Unlawful Act Excludes the Possibility of Misadventure in an \\ Unintentional HoMicide}

While the concept discussed in the preceding section has gradually entrenched itself in our law, one can not but be amazed to find that it has become a well recognized rule of law with hardly any discussion as to its intrinsic merits. ${ }^{12}$

8. It was at about this time that some clear cases illustrative of the principle of aberratio delicti as applied to homicide had been decided. These are cases of homicide in the commission of an unlawful act, which is of the same quality and gravity as the one actually perpetrated. See Anne Gore's Case, 9 Co. Rep. 8I (a) (K. B. I6II).

9. I2 Mod. 627 (K. B. I7OI).

10. $4 \mathrm{BL}$ ConrM. *I82, I9I.

II. Car. \& Mar. 236 (184I).

12. This concept, let it be remarked, is not peculiar to the Anglo-American law. It is firmly established, though in a different form, in some of the continental codes.

France: CODE PÉNAL (1810) art. 319: "Quiconque, par maladresse, imprudence, inattention, négligence ou inobservation des réglemens, aura commis involuntairement, 
It will be shown in subsequent portions of this article that the law on this subject can not generally be regarded as based on the principle that a person is responsible for the natural and probable consequences of his act. The decided cases transcend the application of this principle. The real reasons for the rule are historical. It is submitted that one of the reasons may be found in the strained and abnormal construction which the law came to apply to the concept of malice. This thesis is borne out to a large extent by the fact that, with minor exceptions, the principle of aggravation of an unintended offense by the commission of another offense which was contemplated by the defendant, has found application exclusively in the field of homicide which came to be colored by the ill-defined concept of malice. ${ }^{13}$ Cases have arisen in which even the hard-thinking, common-law judges found it to be an exaggeration to base conviction on the ground of implied malice, and it appeared to them to be more satisfactory to say that the defendant ought to be con-

un homicide ou en aura involuntairement été la cause, sera puni d'un emprisonnement de trois mois à deux ans, et d'une, amende de cinquante francs à six cents francs."

("Whoever shall involuntarily commit a homicide by unskilfulness, imprudence, inattention or non-observance of the rules, or shall involuntarily have been the cause thereof, shall be punished by imprisonment from three months to two years and by a fine of 50 to 600 francs"- the author's translation.)

Germany: STRAFGESETzBUCH (1870) art. 2I4: "Wer bei Unternehmung einer strafbaren Handlung, um ein der Ausführung derselben entgegen-tretendes Hindernis zu beseitigen oder um sich der Ergreifung auf frischer Tat zu entziehen, vorsätzlïch einen Menschen tötet, wird mit Zuchthaus nicht unter zehn Jahren oder mit lebenslänglichem Zuchthaus bestraft."

("Whoever kills a person intentionally in the undertaking of a punishable act in order to remove an obstacle to the execution of the same or to withdraw from apprehension in the very act, will be punished with imprisonment for a period not less than Io years or for life"-author's italics and translation.)

It will be noted immediately that the German code makes unlawfulness of action a factor in the punishment of a homicide only when the homicide is intentionally committed. Article $2 \mathrm{I} 4$ is not applicable to a case where the defendant acted with premeditation. Such case comes exclusively within article 211 , defining murder as the "intentional, deliberately executed" killing. German Supreme Court, Sept. 17, 1885, I2 Entscheidungen des Reichsgerichts in Strafsachen 364 ; FRANK, DAS STRAFGESETZBUCH FÜR DAS DEUTSCHE REICE, II 214.

Article 2I4 was construed to represent not an independent factual situation, but merely a qualified instance of an aggravating character of article 212 (defining manslaughter as an intentional killing without premeditation). German Supreme Court, June II, I885, I2 Entscheidungen des Reichsgerichts in Strafsachen 250 .

Also, it is not necessary that the defendant be actually apprehended, but sufficient if preparation for such apprehension be made and if the defendant perpetrate the killing, hoping to escape. I BINDING, HANDBUCE 30. A mistaken belief on the part of the wrongdoer in the existence of such obstacle or danger of apprehension is sufficient to satisfy the requirements of article 2I4. To this effect see OBERMIEYER, REICHS STRAPGESETZBUCH KOMMENTAREN (I920 ed.) 550. Lastly, it is not necessary for the purposes of this aggravated manslaughter that the victim be the one actually intended by the defendant. German Supreme Court, June 12, 1922, 57 Entscheidungen des Reichsgerichts in Strafsachen 67.

13. One of the rare instances where this principle of aggravation has been applied to a case other than homicide is to to be found in the case of Commonwealth v. Adams, Ir4 Mass. 323 (I873). In that case the Commonwealth pressed for a conviction for an aggravated assault and battery on the ground that it was committed while the defendant was engaged in the commission of an unlawful act, viz, driving at an excess rate of speed. 
victed because he was engaged in the commission of an unlawful act. A case of this type ${ }^{14}$ was one in which two people were engaged in playing with sword and buckler (not a case of dueling, in the course of which a homicide was always regarded as murder at common law ${ }^{15}$ ), and one was killed. Where two men consented in a friendly manner to practice swordsmanship, no malice of any kind could be detected even by the sternest observer, yet it appeared too "liberal" not to condemn the defendant as a felon. To say that the defendant was guilty because he was engaged in an unlawful act seemed to be the best way out of the dilemma. ${ }^{16}$

A concurrent explanation of the rule may be found in the theological and economic background of the common law. Mr. Justice Holmes' statement to the effect that not logic but experience was the driving force in the development of our law is well illustrated by the social traditions which, perhaps more than anything else, were responsible for the evolution of the doctrine here under consideration. There are ample indications in the old text-books dealing with the subject of homicide that the idea of "loss", in one form or another, was considered a factor greatly responsible for the unchallenged understanding that homicide when accompanied by a certain animus, is the most heinous of all crimes. This notion, a remnant of the old Anglo-Saxon law which treated homicide principally as a civil wrong, survived even the period when the penal and socio-protective aspects of the criminal law gained the ascendancy. "Murder", says Blackstone, "is an injury to the life of an individual; but the law of society considers principally the loss which the state sustains by being deprived of a member. . . ." 17 This idea of an infringement of a possessory interest-of a damage having been occasioned-is also alluded to by other common-law writers. Hale is even more emphatic in this assertion. ${ }^{18}$ Foster in one place expresses this idea of a "loss" in the words, "the mischief done is irreparable".18 Viewed in this light, the numerous common-law forfeitures were more compensatory than penal in the strict sense of the term. It would seem,

14. 4 BL. CoMn. *Igr.

I5. Stanley's Case, Kel. J. 86 (I663) ; Lord Morley's Case, Kel. J. 53 (I666).

I6. In Regina v. Greenwood, $7 \mathrm{Cox} C$ C. 404 (1857), the facts were that $D$ committed rape on $V$ and gave her a venereal disease. $V$ died as a result of this sexual connection. The court told the jury that the only malice possible in the case was malice implied in law, $i$. e., implied from the commission of a felony (an unlawful act). When the jury failed to bring in a verdict of guilty of murder, the court instructed the jury that they might "ignore the doctrine of constructive malice". Thereupon, the jury brought in a verdict of guilty of manslaughter.

I7. 4 BL. CoMrs. *6.

18. I HALE, Pleas of THE CROWN *4I2 et seq., where he assigns the infringement of God's and the King's interests in a subject as the reason why suicide is deemed to be criminal. See also id. at *477, where the same is offered as a justification for the forfeiture in cases of homicide by misadventure.

19. FOSTER, op. cit. supra note 5 , at $29 x$. 
therefore, that when the idea was gradually evolved that a homicide unintentionally caused while doing some other unlawful act was murder or manslaughter, the underlying reason was a desire to avenge the loss to society caused by the defendant, however innocent his mind may have been with regard to the crime for which he was being tried.

We may go even farther, and advance the suggestion that when the common law evolved the idea of punishing a homicide accidentally caused while doing an unlawful act, the law was not aiming primarily at punishing the defendant for the homicide, but at punishing him for the "unlawful act", which in the great majority of cases consisted of a violation of a plain and ordinary property right. This apparently radical suggestion will perhaps appear less exaggerated when we reflect that often greater freedom of action was allowed in defense of one's realty and chattels than in defense of life, which was evidently a less readily perceptible interest. ${ }^{20}$ Killing a robber on a highway was a justifiable homicide, while killing an adulterer found in flagrante delicto was at least manslaughter. A bare trespass upon one's real estate was regarded as sufficient provocation to reduce a homicide to manslaughter. ${ }^{21}$

By far the most telling examples of the zeal with which certain property interests were defended by the common law are contained in a long series of enactments relative to hunting in certain forests and parks. Thus we read that trespassers in a "forest, chace, or warren", could be killed with impunity even when the trespasser did not offer any active resistance to arrest but merely fled. ${ }^{22}$ To wound a deer in an enclosed deer-park was made an unclergyable felony. ${ }^{23}$

Illustrations evincing a distinct tendency to protect certain proprietary interests at the expense of human life can easily be multiplied, but those already mentioned will adequately serve the purpose. When to this historical fact is added mention of the social order with its various group prerogatives, ${ }^{24}$ the suggestion here made that the purported punishing of the accidental homicide was only a handy pretext

20. I Hale, Pleas of the Crown *48I, 492 ff; see also Hale Summary of Pleas OF THE CROWN *39, 40.

21. In Hollowayes' Case, Jones, W. 198 (C. B. I620), an owner of realty was held guilty of murder for having caused the death of a trespasser, but the facts of the case disclose that the defendant tied the victim, a young boy, to the tail of a horse and galloped the horse for a long time until the boy died.

22. 2I EDW. I, c. 2 (1293); 3 \& 4 W. \& M. c. Io (169I).

23. 9 GEo. I, c. 22 (I722). Destruction of a timber tree at night was punished with transportation for seven years. 6 GEO. III, c. 36 (I765). A person having any sticks of wood of another in custody without being able to explain how he obtained them was subject to a fine, and upon third conviction was branded an incorrigible rogue and pumished as such. 6 Gro. III, c. 48 (I765).

24. Killing in a tournament at the King's command was justifiable; otherwise, manslaughter. 4 BL. COMM. *I92; MYRROR OF JUSTICE, c. I, \& I3. Benefit of clergy was, perhaps, the greatest class prerogative as far as the criminal law was concerned. For an account of this subject, see I PIKE, A History of Crime IN ENGLANd (I873) 297 et seq. 
for avenging a violation of a property right by an unlawful act will not seem as devoid of foundation as it might have seemed at first glance.

2. What is to be UNDerstood by the Term "Unlawfulness" of THE ACT UPON WHICH THE CULPABILITy FOR THE Unintentional Homicide is Predicated

Whatever may be said as to the raison d'etre of the doctrine here under discussion, its existence as part of our law is almost universal in this country and its essential utility is, as yet, uncontested. Furthermore, besides that species of involuntary manslaughter committed while the defendant is engaged in the doing of some unlawful act, our common law also regards as felonious an involuntary manslaughter which occurs as a consequence of doing a lawful act in a negligent manner. In the light of this situation it becomes important to inquire into the proper scope and limitations of the concept of "unlawfulness" which is the essential element in the definition of the former species of involuntary manslaughter here referred to.

The substantive connotation of the term "unlawfulness" as well as the method by which it may be determined are by no means settled. In Potter v. State, ${ }^{25}$ the court said, "the law . . . considers as unlawful all acts which are dangerous to the person against whom they are directed. . . ." In Regina $v$. Bradshaw, ${ }^{26}$ the facts were that in the course of a football game $D$ killed $V$ by charging at him under circumstances which took this behavior out of the rules of the game. Bramwell, J., charged the jury that the only question for them to consider was whether $V$ died of $D$ 's unlawful act, and further stated that the law of the land regards as unlawful "that which is likely to cause the death of another". ${ }^{27}$ It is to be noted that the presence or absence of negligence was not made a point of issue in this case though the definition of unlawfulness which the court laid down is broad enough to include negligence. To act without proper care whereby death might ensue would be unlawful within the court's definition, but failure to observe due care is quite properly not made an indispensable element of unlawfulness. The definition so broadly stated is probably not a correct statement of the law. Applied literally it would render many inherently dangerous industrial activities unlawful by the mere fact that they are "likely" to cause death. A sounder test of unlawfulness

25. I62 Ind. 213, 217, 70 N. E. I29, I3I (1904).

26. $I_{4}$ Cox C. C. 83 ( 1878 ).

27. Id. at 84. See 2I AM. \& ENG. ENcyc. of LAw (2d ed. I902) I9I, where it is likewise stated that doing anything which jeopardizes the personal safety of individuals is unlawful. In State v. Woods, 7 Penne. 499, 500, 77 Atl. 490 (Del. I896), the court says that the unlawful act constituting an element in the crime of involuntary homicide is any act which one has no right to do. 
of an act which was alleged as the gist of a criminal proceeding for involuntary manslaughter is to be found in Queen v. Bruce. ${ }^{28}$ In that case the court opines that in order for such an unintended homicide to amount to manslaughter, the defendant must be in pursuit of an unlawful object. This opinion represents a commendable shift of emphasis from the objective unlaw fulness of a given situation to the unlawfulness of the purpose which motivated the defendant's antecedent conduct. ${ }^{29}$

Still another source of confusion in the understanding of the term "unlawfulness" in this connection are the cases in which negligent conduct is deemed to be unlaw ful if it results in the death of a human being. Some of those cases go only as far as to say that a high degree of negligence is the equivalent of unlawfulness, while others refer to any degree of negligence as unlawful. In State $v$. Dorsey, ${ }^{30}$ the court construed the words "unlawful act" in a statute defining manslaughter, as including negligence while doing a lawful act. A statute which codified Blackstone's definition of manslaughter was up for construction before the same court in Dunville v. State, ${ }^{31}$ and the court said that the words in the statute must be taken to be as broad in their content as they were at common law and, therefore, a homicide by "wanton recklessness" is within the statute defining involuntary manslaughter to be a homicide committed by the defendant while he was doing an unlawful act. In Regina $v$. Longbottom, ${ }^{32}$ the defendant, partially intoxicated, was driving rapidly and without requisite care on a public highway near a town when he killed $V$. Instead of adjudging the case on the ground of its being one where a homicide was committed in the commission of a lawful act done in a negligent manner or in the commission of an unlawful act, i. e., on the grounds of either of the two separate types of involuntary manslaughter known to the law, the court went out of its way to say that the defendant was guilty because the manner in which he had been driving constituted "that degree of negligence which amounts to an illegal act in the eyes of the law. . . ."

28. 2 Cox C. C. 262 ( 1847 ).

29. I5 VINER, loc. cit. supra note 2, cites BRook, CoRone 228, to the effect that a killing caused by casting a stone over a house may be a felony or misadventure, depending on whether the casting was lawful. This criterion of lawfulness is definitely couched in terms of the ultimate object sought to be attained by the defendant. He says that the casting is lawful when one untiles a house for the purpose of "new covering it"; unlawful, when the casting is done in sport or for his pleasure, "and not in lawful labor".

30. II8 Ind. 167,20 N. E. 777 (I889).

31. 188 Ind. 373,123 N. E. 689 (1919).

32. 3 Cox C. C. 439,440 (I849). See also Regina v. Dant, [1865] Leigh \& C. 567. In United States v. Meagher, 37 Fed. 875, 880 (C. C. W. D. Tex. I888), the court uses the following language: "Any unlawful and willful killing of a human being without malice is manslaughter, and, thus defined, it includes a negligent killing, which is also willful." 
Manslaughter cases arising under the various automobile codes often present instances of ideal concurrence of the elements of negligence and unlawfulness. Some of these codes provide a flexible standard requiring drivers to drive carefully in view of all the circumstances. Guilt for manslaughter where a violation of the abovementioned statutory provision is charged as the basis of the offense against life, ${ }^{33}$ may as properly be put on the ground of the commission of an unlawful act as upon the ground of negligence while doing a lawful act, since a verdict of guilty in a case of this nature is an implied finding that the defendant was negligent. ${ }^{34}$

The failure of some courts to keep separate and distinct the two kinds of involuntary manslaughter ${ }^{35}$ is not confined to instances of calling negligent conduct unlawful. Appellate courts have sustained convictions of manslaughter for killing in the commission of an unlawful act on the ground that the violation of the law is evidence of negligence. In one case, ${ }^{36}$ the court instructed the jury that driving at an unlawful rate of speed in violation of a statute was prima facie negligence. In another case, the court went even farther and held that the violation of a speed statute was ipso facto negligence. ${ }^{37}$

It is erroneous to refer to a homicide caused by a person while doing a lawful act in a negligent manner as an involuntary manslaughter in the perpetration of an unlawful act. ${ }^{38}$ While this indiscriminate

33. Schultz v. State, 89 Neb. 34, r30 N. W. 972 (IgII) ; State v. Rountree, I8I N. C. 535 , 106 S. E. 669 (I92I).

34. Except where the violation alleged is that $D$ exceeded the maximum speed limit, which was made a punishable offense irrespective of due care by the defendant. It is worthwhile to add that a conviction of the type just mentioned has often been appealed on the ground, among others, that such conviction is a violation of the constitutional right to be informed of the nature and cause of the accusation. The gist of the contention in such case is that an allegation in the bill of indictment that the defendant caused the victim's death by "not driving with proper care in view of the circumstances" does not give the defendant sufficient information as to the charge against him. In Hayes v. State, II Ga. App. 37I, 376, 75 S. E. 523, 525 (I9I2), the court remarks that to hold such a statute valid would amount to making criminality dependent upon "idiosyncracies of the individual who may happen to constitute the court and jury. . " But cf. State v. Schaeffer, 96 Ohio St. 2I5, II7 N. E. 220 (I9I7), where the court held such a statute to be constitutional.

35. Homicide in the commission of an unlawful act, and homicide caused in the commission of a lawful act in a negligent manner. For discussion of the first kind of manslaughter here mentioned see Notes (Ig04) 63 L. R. A. 353, (Ig03) 90 AN. ST. REP. 57I.

36. State v. McIvor, 3r Del. I23, III Atl. 6I6 (I920).

37. Lauterbach v. State, I32 Tenn. 603, I79 S. W. I30 (I9r5). In People v. Mount, 93 Cal. App. 8r, 269 Pac. I77 (I928), the court held that the use of a forbidden medical instrument by a chiropractor was negligence in itself, and that the chiropractor was therefore guilty of involuntary manslaughter when the patient upon whom he had used such an instrument died.

38. The fact that the aggravated manslaughter in the German penal law is of a voluntary character makes it impossible to distort legal principles in this manner. The French law on this subject (CODE PÉNAL (I8I0) art. 3I9, quoted supra note I2), while it does contain a provision about an involuntary homicide "by inobservation of rules", draws a sharp line between this species of manslaughter and the one caused by negligence. The French law seems to be clear that there may be a conviction of the former 
nomenclature merely amounts to a merger of the two kinds of involuntary manslaughter known to the law, the labeling of a homicide caused while doing something admittedly unlawful as "negligence" is likely to raise difficulties which, for the sake of procedural certainty, it would be best to avoid. ${ }^{39}$

On the other hand, legal authority is fairly unanimous in holding that even though an intent to do the forbidden act is necessary before a conviction for manslaughter may be predicated on such unlawful act, no specific intent to violate the law rendering the act unlawful is necessary. It is deemed sufficient that the defendant did the forbidden act of his free will, having intended to do that act. ${ }^{40}$ The defendant's belief that the act he was doing was not dangerous to human life appears to be of no moment in the majority of cases, though occasionally an opinion to the contrary may be found. ${ }^{41}$ Consent of the victim to the commission of the unlawful act upon him or in relation to him does not make the act lawful as far as a prosecution for manslaughter resulting therefrom is concerned, even if such unlawful act does not, per se, constitute a breach of the peace. ${ }^{42}$

kind of homicide irrespective of any negligence. In a case decided by the Cour d'Angers, May 27, 1867, Dalloz Jurisprudence, 1867 II. 220 , a director of a slate quarry was held criminally responsible for the death of an operator caused by the defendant's failure to maintain certain service paths as he was required to do by statute, even though by contract he sought to shift this duty to the mine foreman. The presence or absence of negligence in this breach of statutory duty was not made an element in the decision against the defendant. No point was made of the element of negligence in a similar case decided by the Cour de Cassation, Feb. 22, 1883, Dalloz Jurisprudence, I883 I. 487 , where an employer was convicted for causing the death of a minor less than sixteen years of age by failure to provide a machine with certain safety appliances as required by statute.

39. If an unlawful act be held tantamount to negligence in cases of involuntary manslaughter, the argument might be advanced that the record of conviction in the criminal trial should be admitted as some evidence of negligence in a subsequent civil action for death by wrongful act. While such a conclusion would seem to be a logical consequence of this line of reasoning, yet to admit such a record as evidence would involve basing civil liability on the most fictitious kind of negligence known to the law.

40. State v. Goodley, 9 Houst. 484, 33 Atl. 226 (Del. I889); Siberry v. State, I49 Ind. 684, 39 N. E. 936 (I895) ; People v. Fitzsimmons, 34 N. Y. Supp. I I02 (Ct. Sess. I895).

In Germany, likewise, legal opinion is to the effect that a mere negligent commission of a criminal act does not supply the requirements of article 214, OBERMEYER, loc. cit. supra note 12 .

French law is in accord. See case decided in Cour de Cassation, Feb. 22, I883, Dalloz Jurisprudence, I883 I. 487.

4r. Strickland v. State, 37 Ariz. 368, 294 Pac. 6I7 (I930), holding that a bona fide belief by the defendant that he was in rightful possession did not prevent the accidental killing of $V$, who came on the premises with the object in mind of dispossessing $D$, from being manslaughter in view of a statute which made forcible detainer a misdemeanor. Cf. State v. Trent, 122 Ore. 444, 252 Pac. 975 (1927), petition for rehearing, I22 Ore. 463,259 Pac. 983 (I927). In People v. Barnes, I82 Mich. I79, I48 N. W. 400 (rgI4), the court was of a different opinion. That court held that it was a question for the jury whether the defendant in good faith believed himself to be driving at a permissible rate of speed, i. e., mistake of fact in the violation of a statute was made a pertinent inquiry in a trial for manslaughter in the commission of an unlawiul act.

42. State v. Center, 35 Vt. 378 (I862) ; Regina v. Bradshaw, I4 Cox C. C. 83 (1887). In Regina v. Bruce, 2 Cox C. C. 262 (1847), it seems that $X$ 's consent vitiated 
Irrespective of the substantive implications of the concept of unlawfulness as applied to cases of involuntary manslaughter, there is likewise some uncertainty to be noted in the legal method by which such unlawfulness may be determined. In states which have codified the common-law definition of manslaughter or have, by silence, left this subject to be governed by the common law, a question often arises as to whether the term "unlawful act" is broad enough to include acts which were not offenses at common law but which are made unlawful by statute. State $v$. Trent ${ }^{43}$ and People v. Abbott ${ }^{44}$ answered this question in the affirmative. There are jurisdictions, however, in which the existence of common-law offenses is denied by their respective constitutions, and in those jurisdictions it is held that for an unlawful act to come within the definition of involuntary manslaughter, such act must be declared unlawful by the legislature. ${ }^{45}$ In this latter group of jurisdictions, as well as in the jurisdictions which hold that the commonlaw rule is broad enough to include offenses created by the legislature, it is usually held that an act declared to be unlawful by an ordinance of a county or of a municipality is sufficient for the purpose of a conviction for manslaughter. ${ }^{46}$ The majority of the courts before whom this question has been argued have, however, reached an opposite result despite the fact that the promotion of the safety of individuals was the obvious purpose of such an ordinance. ${ }^{47}$

the unlawfulness of the act even as respecting $B$, a third party, who did not consent. State v. Bickel, I77 S. W. 310 (Mo. I9I5), held that consent to an abortion is no defense to an indictment for manslaughter based on the woman's death caused by the abortion.

43. I22 Ore. 444, 252 Pac. 975 (I927). There, the unlawful act was one regarded by the court as malum in se.

44. I16 Mich. 263,74 N. W. 529 (I898).

45. Johnson v. State, 66 Ohio 59, 63 N. E. 607 (I902); Hayes v. State, II Ga. App. 37r, 75 S. E. 523 (19r2).

In France the word "reglements" in article 319 of the CODE PÉNAL (see supra note I2) is construed to include not only specific decrees and legislative orders, but also the general body of laws which contains measures for the promotion of public health and security. See I Garçon, CODE PÉNAL (IgOr) 777, § 23. But cf. id. at 787, § I29. Note, however, that to come within these "reglements", the act prohibited must be more than one of a mere administrative nature relative to the proper execution of public works, etc. That is to say, the law declaring the unlawfulness must be of the nature of a general police measure. Dalloz Jurisprudence, 185I V. 527; I GaRcon, op. cit. supra at $776, \S \mathrm{r2}$. Furthermore, the violation of one of the aforementioned rules is a basis for conviction of manslaughter only as to those persons upon whom the law casts a personal duty. As to their servants, agents, etc., their criminal liability for manslaughter, if any, is usually grounded on negligence for failure to perform the duty which was delegated to them by their master or principal. See id. at $778, \S 35 ; i d$. at $783, \S 84$.

46. See Johnson v. State, 66 Ohio 59,63 N. E. 607 (I902); Hayes v. State, II Ga. App. 37I, 75 S. E. 523 (Igr2). In State v. Sandvig, I4I Wash. 542, 25I Pac. 887 (I927), a conviction of manslaughter for a killing committed while in the commission of an act made unlawful by ordinance, was set aside on the ground that the ordinance was not well pleaded. But cf. People v. Davis, I Ill. C. C. 245 (1906), which impliedly recognizes an ordinance as sufficient to render an act unlawful for the purpose of manslaughter.

47. State v. Collingsworth, 82 Ohio St. I54, 92 N. E. 22 (1910). See also People v. Pearne, II8 Cal. I54, 50 Pac. 376 (I897). In State v. Born, 85 Ohio St. 430 , 98 
Assuming the existence of an "unlawful act", whether by the common law or by statute, the problem arises whether a criminal penalty is an essential ingredient of unlawfulness. Differently stated, the problem is whether that species of unlawfulness described as a civil trespass is a sufficient foundation for a conviction of involuntary manslaughter. The view which prevailed at common law seems to be that a mere civil trespass is adequate for this purpose. Hale was of this opinion. ${ }^{48}$ The definition offered by East is equally broad. ${ }^{49}$ While some English cases have adopted this view, ${ }^{50}$ a different tendency is revealed by contemporary case law. ${ }^{51}$

The American cases, likewise, seem to require that the unlawful act be at least a misdemeanor, i. e., that the act be of such a degree of unlawfulness as would entail penal consequences even if no homicide were to result from its commission. There are, however, cases to be found in which an opposite conclusion was reached. The unlawful acts involved in those cases are of the category usually labeled mala in se. Commonwealth $v$. Mink ${ }^{52}$ will serve well to illustrate this type of case. The defendant, while attempting to commit suicide by shooting herself in the head, accidentally killed someone who tried to wrest the pistol from her hand. By the then-governing law of Massachusetts neither suicide nor an attempt to commit suicide were punishable as an offense, nor indictable as such. The reviewing court in upholding the conviction

N. E. 108 (IgI2), the court refused to admit an ordinance even for the purpose of proving that a certain locality which was the scene of the homicide caused by the defendant's excessive speed, was a closely built up section. For a general statement see 13 R. C. L. 848.

48. I Hale, Pleas of the Crown *38: "So it is if he be doing an unlawful act, though not intending bodily harm of any person as throwing a stone at another's horse, if it hit a person and kill him, this is felony and homicide and not per infortunium."

49. I East, Pleas of the Crown *257.

50. Regina v. Fenton, I Lew. C. C. I79 (I830) ; Rex. v. Sullivan, 7 C. \& P. 64r (1836). In I BishoP, CRIMINAL LAW (9th ed. I923) $\$ 330.2$, it is said: "For a crime does not of necessity and in all circumstances require a greater evil of intent than a civil tort. So that when one intending only a civil or even only a moral wrong, does accidentally an unintended act to the public detriment of sufficient magnitude and of the kind punishable as a crime, this result subjects him to indictment."

5I. Regina v. Franklin, I5 Cox C. C. I63 (r883); Rex v. Baldessare, I44 L. T. R. I85 (Cr. App. I930).

52. I23 Mass. 422 (I877). It is interesting to speculate upon the possibility of a conviction if, under the circumstances of the case, $V$ had killed $D$. See also State v. Horton, I39 N. C. 588, 51 S. E. 945 (I905), where the court says that even a civil trespass may be malum in se.

France: Garcon makes the statement that criminal guilt for manslaughter under article 3 rg of the Code Pénal is not affected by the fact that a violation of the rules or regulations in the commission of which the homicide occurred does not, by itself, entail a penalty. Garçon, CODE PÉNAI, (IgOI) 778, \$28.

Germany: The act "undertaken" within the meaning of article 2I4 of the Strafgesetzbuch must be punishable, but only in an objective sense. That is to say, the act is considered punishable if the law provided the penalty for its commission, even if for some peculiar reason, such as extenuating circumstances, this particular defendant would not be subject to the penalty. See Lyszt, Lenrbuch des Deutschen Strafrecerts (I92I ed.) 3I7; I BiNDING, LeHRBUCH 30. 
for involuntary manslaughter said, "suicide being unlazeful and criminal as malum in se, any attempt to commit it is likewise unlawful and criminal".

It would seem that if "unlawfulness" of an intended act is to be made a factor in deciding the guilt or innocence of its perpetrator for an unintended homicide, it should be based on a criterion other than the theoretical classification of those acts into felonies, misdemeanors and trespasses, or upon the oftentimes incidental circumstance of the presence or absence of a penalty for that intended act. The unlawfulness of that act should rather be judged by the motives which governed the defendant in his behavior and by whether there should have been a reasonable anticipation of danger to human life likely to follow from that act. ${ }^{53}$

\section{The Nature of the Act which if Unlawful Will Render the Accidental Homicide an Involuntary Manslaughter.}

Hitherto our discussion has been solely concerned with the extent and limitation of the concept of "unlawfulness". At this point a few remarks might profitably be made with reference to the scope of the act which, if unlawful, will render an accidental homicide criminal. The physical properties of these acts, as illustrated by the decided cases, are so manifold and varied that no worthwhile purpose would be served by their enumeration or classification. Their wide range includes such acts as racing on a public highway, ${ }^{54}$ forcibly evicting from real estate a person in possession, ${ }^{55}$ performing abortions, ${ }^{56}$ pointing firearms, ${ }^{57}$ etc. It is of some interest, however, to point out their general nature.

It will be remembered that the common-law definition of involuntary manslaughter contained the phrase "in the commission of some unlawful $a c t ",{ }^{58}$ a definition which is reiterated in most of our state

53. See, in connection with "constructive homicide", Regina v. Skeet, 4 F. \& F. 931 (I866), and an editorial note in I76 Eng. Reprints 855. Certain types of cases involving homicide caused by racing at excessive speed on highways, or pointing of fire-arms are usually put on grounds of negligence or recklessness, even though they might have been put on the unsatisfactory ground of unlawfulness. See, for example, Regina v. Jones, I2 Cox C. C. 628 (I874). 2 Bishop, op. cit. supra note 50, $\$ 69 \mathrm{r}$, also goes part of the way when it says, "One unintentionally taking life in committing a mere criminal misdemeanor dangerous to life, so that the element of danger concurs with the unlawfulness of the act, commits murder".

54. Regina v. Swindall \& Osborne, 2 Car. \& Kir. 230 (1846).

55. People v. Honshell, ro Cal. 83 (I858).

56. People v. Seaman, I07 Mich. 348, 65 N. W. 203 (1895) ; State v. McLeod, I36 Mo. rog, 37 S. W. 828 (I896); State v. Power, 24 Wash. 34,63 Pac. III2 (Igor), 63 L. R. A. 902 (1904).

57. Henderson v. State, 98 Ala. 35, I3 So. I46 (1892); State v. Benham, 23 Iowa 154 (1867). In Robertson v. State, 2 Lea 239 (Tenn. 1879), the court held that pointing of fire-arms is not an unlawful act unless it amounts to an assault.

58. 4 BL. CoMm. *rgr. (Italics supplied.) 
codes. $^{59}$ This leaves open such questions as whether an attempt to do one of those unlawful acts is a sufficient "unlawful act"; whether a homicide accidentally brought about after the completion of the crime proper, but within the res gestæ of the act, may be said to have been committed "in the commission" of an unlawful act, etc. This is a subject which has had the benefit of very little judicial interpretation, but it seems to be admitted that it is not necessary for the unlawful act to have been consummated in order to attach culpability to the unintended homicide. This was expressly held in Commonwealth v. Mink, a case alluded to previously, and seems to be the accepted legal opinion in the abortion cases. ${ }^{60}$ A very extreme case of the latter type is the case of Wilson $v$. Commonwealth. ${ }^{61}$ In that case the defendant had used certain instruments upon $V$ for the purpose of procuring an abortion, which use resulted in $V$ 's death. The law of Kentucky was that it was not a punishable offense to procure an abortion of a woman not quick with child, and there was great uncertainty as to whether $V$ was pregnant at the time. Upon this state of facts and law the supreme court of Kentucky affirmed a conviction of voluntary manslaughter, and held proper an instruction of the lower court to the effect that the defendant should be found guilty if he made the efforts to procure an abortion, believing $V$ to be pregnant, even though in fact $V$ zeras not pregnant. Reduced to legal terminology, and without a consideration of whether $D$ could have been guilty of an "attempt" under the facts as stated, this case stands for the proposition that an involuntary homicide committed in an attempt to do an act not considered an offense at common law and not punishable by statute, is punishable as a voluntary manslaughter.

Since the factual situations wherein a homicide is accidentally committed in an attempt at a misdemeanor are comparatively rare, and in view of the fact that the scattered instances where it did become the subject of judicial opinion are of the malum in se category, a statement as to what the courts would decide in cases where a homicide is committed while attempting an unlawful act which is regarded as being merely malum prohibitum would be purely speculative. It is a safe deduction that those courts which still draw the distinction between acts mala in se and acts mala prohibita and which hesitate to convict for manslaughter even in cases where a homicide occurred in the actual commission of an act merely mala prohibita, will a fortiori refuse to

59. CaL. Penal Code (Deering, I93I) § I92. Note particularly N. Y. Penal LAW ANN. (Gilbert, 1935) § 1050, which includes attempts to do an unlawful act in the definition of manslaughter.

60. 2I AM. \& ENG. ENCYC. OF LAW (2d ed. 1902) 190, and cases cited therein.

6r. 22 Ky. L. Rep. I25I, 60 S. W. 400 (I90I). 
convict where the homicide resulted while merely attempting to do that unlawful act. ${ }^{62}$

By analogy to homicide committed in the commission of a felony some courts have adopted the test of res gesta as a criterion in determining when a homicide may reasonably be said to have been perpetrated "in the commission" or "in the doing" of an unlawful act." If this analogy be literally followed, we would have to hold that an unintended homicide committed even after the full consummation of the unlawful act, or after the attempt at its perpetration was abandoned owing to fear of prevention or detection, would still constitute involuntary manslaughter provided it occurred as an incident of a continuous transaction. While this seems to be the accepted doctrine in cases of homicide committed while $D$ is engaged in the perpetration of a felony, ${ }^{64}$ it is hard to believe that a court would so hold (nor is it desirable that it should) in cases of manslaughter where the unlawful act is one not having any hostile or anti-social animus. ${ }^{65}$

Though the general run of cases dealing with involuntary homicide based on unlawful conduct of the defendant at the time of the fatality is such as involves positive wrongdoing of some kind on the part of the defendant, there is no reason to limit the application of the rule in a manner which will exclude cases in which the unlawful conduct consisted in a failure to heed a positive command of the law, i. e., cases of omission to perform a legal duty. This type of unlawful failure to act is usually treated under the branch of involuntary manslaughter in which the homicide is caused by the defendant while engaged in lawful work in a negligent manner, but it is quite conceivable to have such a

62. On the distinction of malum in se and malum prohibitum in cases of homicide see infra p. 826. In a jurisdiction where a mere trespass is held not to constitute a sufficiently unlawful act, a good argument against convictions in cases of homicide occasioned while attempting an act malum prohibitum might be made on the principle that such attempts are usually not regarded as indictable offenses, and therefore the act is not unlawful. Whiteside v. State, II Lea 474 (Tenn. 1883). See Commonwealth v. Willard, 22 Pick. 476 et seq. (Mass. 1839); Wharton, Comparative Criminal Jurisprudence (I883) 4 Crm. L. MAG. I, I4.

63. People v. Mulcahy, 3I8 Iil. 332, I49 N. E. 266 (1925); Bissot v. State, 53 Ind. 408 (I876) ; see Reed v. State, II Tex. Ct. App. 509, 518 (I882).

64. State v. Gray, I9 Nev. 212, 8 Pac. 456 (I885); see Commonwealth v. Lessner, 274 Pa. I08, III, II8 At1. 24, 25 (Ig22).

65. It is interesting to compare this phase of the discussion with the corresponding statements to be found in the German law books, where the word "unternehmung" ("undertaking") in article 2r4 of the Strafgesetzbuch was the subject of considerable doubt. The phrase, "in the undertaking of" (see supra note 12) is very broadly construed to include, besides acts of preparation and final execution, such acts as are perpetrated by the defendant for the purpose of removing himself or his loot to a position of safety. See LyszT, LemRBUCh DES DeUtSchen Strafrechts (I92I ed.) 31\%. Some go even further and hold the definition to include the homicide of the owner of a stolen chattel who seeks to recover it from the thief immediately after the commission of the theft. OBERMEYER, loc. cit. supra note 12. The phrase, "in the very act", was similarly construed, but the authorities do not go so far as to apply this principle to a killing of a possible adverse witness. See ibid.; 2 Olshousen, KOMMEnTaR zUM STRafgesetzbucH (Ioth ed.) 828 . 
deliberate omission of the same degree of unlawfulness as a corresponding positive wrongdoing. Some cases regard such deliberate omission as a legally sufficient "act". ${ }^{.6}$

On the question of the physical relationship of the unlawful act to the death, some of the early cases laid down the rule that the unlawful act in the commission of which a homicide is held to be involuntary manslaughter must be something other than an assault and battery, i. e., it must not be an ingredient of the killing. In State $v$. Sloan, ${ }^{67}$ the court reasons as follows: "where an act becomes criminal from the perpetration or the attempt to perpetrate some other crime, it would seem that the lesser could not be a part of the greater offense". It is hardly necessary to give serious consideration to this argument which has lately been repudiated by a New York decision wherein the court held that it was not necessary for the unlawful act to be separate and apart from the act of killing. ${ }^{68}$ On general principle there seems to be no reason for holding that an assault and battery where the defendant acts directly with reference to another person is an insufficiently unlawful act.

\section{Malum in Se Contrasted with Malum Prohibitum: A Prob- LEM OF Legal CAUSE AND EFFECT}

\section{A. The Origin of the Distinction between Acts Mala in Se and Mala Prohibita}

The broad statement by Coke that homicide occasioned while doing any unlawful act is murder, probably a true statement of the law as it was then known and applied, ${ }^{69}$ did not survive that eminent author for any appreciable length of time. It was doomed to extinction by its very rigidity. The legal processes by which the harshness of the rule as formulated by Coke was gradually mitigated, operated in two directions. One of those consisted in a more definite division of crime into felony and misdemeanor, accompanied by a steadily growing conviction that homicides, accidentally caused in the commission of a lesser offense, should not entail consequences as serious as those occurring in the commission of a felony. The second process was of greater theoretical

66. See, for example, People v. Harris, 74 Misc. 353, I34 N. Y. Supp. 409 (Ct. Gen. Sess. Igrr). An intimation to the same effect is to be found in State v. Shelledy, 8 Iowa 477 (I859). In People v. Halbert, 78 Cal. App. 598, 248 Pac. 969 (I926), the court upheld a conviction under the third count of the indictment which alleged that the defendant was guilty of a homicide in the commission of an unlawful act in that he had omitted to render aid to and leave his name and address with $V$ after the collision of their cars which later resulted in $V$ 's death. This is an unwarranted stretching of the definition, since as far as this count was concerned the homicide could not be said to have been committed "in the commission" of an unlawful act.

67. $47 \mathrm{Mo.} 604$ (I87I), relying in part on People v. Rector, 19 Wend. 569 (N. Y. 1838). See also State v. Downs, 91 Mo. 19, 3 S. W. 219 (1886).

68. People v. Darragh, I4I App. Div. 408, I26 N. Y. Supp. 522 (Ist Dep't, Igro).

69. See supra p. 812. 
distinction, and its essence lay in the emphasis which was beginning to be put on the necessity for the existence of a causal connection between the unlawful act and the resulting homicide. The distinction between unlawful acts mala in se and those merely mala prohibita, as far as the law of homicide is concerned, appears at first glance to have been an historical outgrowth of the first of the two processes just mentioned, i. e., the development of a finer gradation of criminal offenses in general. It is submitted, however, that regardless of the historical soundness of this impression, the terms mala in se and mala prohibita as applied in the decided cases are merely unfortunate epithets resorted to by some of the courts who fail to appreciate the necessity for a causal connection between the unlawful act and the homicide.

Hale was probably the first to make use of the term malum prohibitum $^{70}$ as a criterion in cases of homicide, and perhaps the one who actually invented it. After stating the case of a man who, while shooting deer in his own park, accidentally kills a person, i. e., a case of misadventure without negligence, and a case of accidental killing while hunting in the park of another, which killing is prima facie culpable, he goes on to say, "By the statute of $33 \mathrm{H}$. 8. cap. 6. "No person not having lands $\mathcal{E} c$. of the yearly value of one hundred pounds per anmum may keep or shoot in a gun upon pain of forfeiture of ten pounds.' Suppose, therefore, such a person not qualified shoots with a gun at a bird, or at a crow, and by mischance it kills a bystander . . . this will be no more than chance medley in him, for though the statute prohibits him to keep or use a gun, yet the same was but malum prohibitum, and that only under a penalty, and it will not inhance the effect beyond its nature." The preamble to that statute states that the purpose of the statute was to prevent people from going armed on the King's highways, thus constituting a danger to public safety, and to encourage the use of the long-bow, which, it is pointed out, fulfilled an honorable function in the defense of England. Hale does not emphasize the first-mentioned purpose of the statute, having taken no cognizance at all of its purpose, but he does emphasize the point that the statute only provides a monetary penalty for its violation. East ${ }^{71}$ and Foster ${ }^{72}$ both use the "qualified man" illustration as contained in the statute cited by Hale as an example of malum prohibitum, also using the descriptive counterpart of malum prohibitum, malum in se. Neither Hawkins nor Blackstone suggest the existence of any such distinction between malum in se and malum prohibitum,

70. I Hale, Pleas of the Crown, **474-475.

7I. I East, Pleas of the Crown, $*_{260}$.

72. Foster, op. cit. supra note 5 , at 259 . 
and the English cases apply it very rarely-significant evidence of the fact that the distinction has not met with universal favor among the common-law jurists. Those common-law writers who recognize the distinction assigned no express reason for their assertion. It is evident, however, that they have regarded the doctrine that an unintended homicide should be punished as a felony by virtue of the oft-times casual coincidence that the defendant was at the same time engaged in the doing of some unlawful act, to be essentially incorrect. This attitude is well revealed by Hale's conclusion that the violation of the statute forbidding certain people to use guns "will not inhance the effect beyond its nature", and from the similar utterance by Foster that the abovementioned violation "will not in a question of this kind enhance the accident beyond its intrinsic moment".

\section{B. The Interpretation of the Terms Malum in Se and Malum Prohibitum}

The majority of the American cases involving involuntary manslaughter adopt the distinction between malum prohibitum and malum in se, and abound with speculation as to their meaning. This is in definite contrast with the English cases where there is hardly any attempt to define the characteristics of these two terms. In some of the American cases the two species of "mala" are distinguished from an historical viewpoint, ${ }^{73}$ i. e., an act malum in se is an act which has been regarded as evil in society for a long time. Other courts find the distinction in the prevailing ethical concepts of contemporary society. Thus we find a statement that an act malum in se is something ". . . naturally evil as adjudged by the sense of a civilized community. . . ."74 Definitions may also be found expressing the thought that an act malum in se is a crime by virtue of some kind of abstract inherent criminality. ${ }^{75}$ By far the greatest number of cases find the rationale for the distinction

73. Thus in People v. Townsend, 2I4 Mich. 267, I83 N. Y. I77 (I92I), the court goes back to Noah, and to China of II20 B. C. to prove its position that drunkenness is malum in se.

74. State v. Horton, 139 N. C. 588, 592, 51 S. E. 945,946 (I905).

75. See I McClain, Criminal, Law (ist ed. I897) \$23. Also i Bishop, op. cit. supra note $5 \mathrm{I}, \$ 334$, where he says that an act malum in se is one "more intensely evil". In Kay v. Vattier, I Ohio 132 (I823), it was held that a contract involving champerty and maintenance was malum in se if any degree of public mischief or private injury was present.

Regina v. Prince, L. R. 2 C. C. I54 (I875), involved a statute which made it a punishable crime to take a girl below a certain age from the possession of the person who had legal custody of her without her father's consent. It was admitted in that case that $D$ honestly believed the girl, who looked quite grown up, to be older than her real age, and that it was reasonable to believe as he did. It was argued on behalf of $D$ that the requirement of a mens rea should be read into the statute under which he had been indicted. The court said that since D's act was wrong in itself, "full scope is given" to the general requirement of a mens rea by applying the statute under consideration literally. 
in the presence or absence of a guilty mind as measured by a subjective standard. ${ }^{78}$ In Thiede $v$. State, ${ }^{77}$ the court finds the essence of malum in se to lie in an intent to commit a wrong against a person or his property. This is to be contrasted with cases of mala prohibita in which the offense consists merely in the doing of the act. ${ }^{78}$ Some courts flatly decline to draw the distinction between an act malum in se and an act malum prohibitum. In Silver $v$. State, ${ }^{79}$ a statute made it a misdemeanor to sell, furnish or give away any opium, morphine, etc., except on a prescription of a physician. The defendant gratuitously injected morphine into $V$ for the purpose of alleviating her sufferings. $V$ died as a consequence of the injection. The court said, inter alia, that even if the question as to what amounts to an unlawful act were not settled by statute and decision, "we would hesitate to concur in the soundness of the view that the unlawful act . . . must be malum in se; for, outside of those things which are condemned as evil or wrong by the Holy Scriptures, the question of what would be evil or wrong in its nature depends on individual conception and environment". An intermediate court of New York seems to be of the same opinion. ${ }^{80} \mathrm{~A}$ number of courts which still adhere to the distinction have made its application depend on various factors. Notable among these are the degree of danger accompanying the doing of the act, and the purpose of the legislature in enacting the statute, ${ }^{81}$ whether to safeguard human lives or merely to protect property.

76. In Dixon v. State, I04 Miss. 4I0, 6I So. 423 (I9I3), the court decided that the simultaneous commission of three separate statutory misdemeanors, viz., carrying a concealed fire-weapon, being drunk on a public highway and shooting on a public highway, was "not naturally evil, not per se vicious or dangerous from which a depraved heart could be inferred", and consequently the defendant was held not guilty of involuntary manslaughter in the commission of an unlawful act for the accidental killing of a woman while thus shooting.

77. 106 Neb. 48,182 N. W. 570 (I92I). In Commonwealth v. Adams, II4 Mass. 323, 324 (1873), the court said, "Acts mala in se include in addition to felonies, all breaches of public order, injury to persons or property, outrages upon public decency or good morals, and breaches of official duty when done wilfully or corruptly". For a similar definition see People v. Davis, I Ill. C. C. 245, 286 (Ig06).

78. People v. Davis, I Ill. C. C. 245 (Ig06). See also Note (Ig2I) 7 A. B. A. J. 493 ; Note (I922) 94 CENT. L. J. I3.

79. 13 Ga. App. 722, 79 S. E. 919 (1913).

80. People v. Darragh, I4I App. Div, 408, I26 N. Y. Supp. 522 (Ist Dep't, 19ro).

8r. Johnson v. State, 94 Ala. 35, ro So. 667 (I89r) ; State v. Custer, 129 Kan. 38I, 282 Pac. I07I (1929); Sparks v. Commonwealth, 3 Bush. III (Ky. I867). See also Note (19I3) 45 L. R. A. (N. s.) 219. In Abbott v. State, II6 Mich. 263, 74 N. W. 529 ( 1898 ), the court being satisfied that an abortion involves some degree of danger declined to make the prohibitory effect of the statute depend on medical testimony by which counsel for the defendant sought to prove that only a trifling percentage of women thus operated on die as a result of such an operation. In People v. Townsend, 214 Mich. 267,183 N. W. I77 (Ig2I), the court pointed out that the purpose of the statute was "to prevent accidents and preserve persons from injuries". 


\section{The Classification of Unlawful Acts into Mala in Se and Mala} Prohibita as Affected by Problems of Causation and Intent

Having indicated what courts understand by malum prohibitum and malum in se it is submitted that the application of the concepts of malum prohibitum and malum in se in the law of involuntary manslaughter is, if literally interpreted, incorrect and totally unnecessary. This criticism may, indeed, be leveled against the original statement and accompanying illustration as offered by Hale. It is proper to recall at this point that Hale's statement, which was copied by only a few common-law writers, was a mere dictum unsupported by any explicit reasoning. As already suggested, this proposition really represented a reaction against the unqualified doctrine that any homicide caused in the commission of a non-felonious but unlawful act was a felony. The criticism of the doctrine, therefore, can not logically be directed toward its substantive merits but rather toward the grounds on which it was sought to be based. The man who kills accidentally while using a gun in violation of a statute which prohibits its use by anybody not having a yearly income of a hundred pounds, should not be guilty of any degree of homicide. The reason, however, should be that there is no causal connection at all between the unlawful act and the homicide, and not the mere formal distinction that the unlawful act was of purely statutory origin punishable by a fine only. The question to be asked is: would not the accident, in all likelihood, have happened just as surely had the defendant had a yearly income of one hundred pounds? Ruling out questions of negligence, and leaving all the other operative facts just as they are, can it be said that the absence of the required property qualifications in any way contributed to the fatal accident? The questions themselves suggest the answer that no causal relation is to be found in the illustration offered by Hale, East and Foster. The reason why the problem was not so approached may be due, in part, to the fact that a strict adherence to the argument as here outlined would have negatived guilt even in the case of a defendant who chanced to kill while hunting unlawfully in the park of another, since even in that case the unlawfulness of the conduct can not be said to be the cause of the homicide. This difficulty, however, does more to demonstrate the wrongfulness of the basic idea underlying the law of involuntary manslaughter in the commission of an unlawful act-even of one which is a malum in se-than to serve as a reason for the dogma that a mere statutory prohibition is not a sufficient "unlawful act".

While it is difficult for us to determine just what the originator of this novel idea had in mind, it is reasonable for us to assume that Hale meant nothing more than the proposition that an unintended 
homicide caused by the defendant while he was engaged in the perpetration of a minor unlawful act, does not entail criminal guilt if the circumstances are such that the homicide can not be said to be the causal result of the unlawfulness of the defendant's conduct. It is unfortunate that Hale, by not elaborating his statement, left open the door for many American courts to misconstrue its true meaning by allowing the label malum prohibitum to obscure the fundamental element of causation in such cases.

\section{The Application of the Doctrine by the American Courts}

In view of the historical background of this doctrine it is of interest to examine the manner in which it is treated by our courts. An attempt will be made to show that practically all of the American cases which have drawn the distinction between the two species of "mala" might more conveniently have been decided on their merits by determining whether there was any causal connection between the unlawful act and the death. We may find three distinct methods of approach to the treatment of an act malum prohibitum as a factor in homicide cases.

Some of our courts, while recognizing the common-law offense of involuntary manslaughter arising from a homicide unintentionally committed in the commission of an unlawful act, proceed upon the premise that an act malum prohibitum, however it may be defined in a given jurisdiction, is not of a sufficiently criminal quality to constitute an unlawful act grave enough to have predicated on it guilt for manslaughter. They insist on a finding by the jury of gross negligence or wilful disregard of the rights of others as a prerequisite for conviction. Those courts entirely dismiss the act which is malum prohibitum as a factor in the case. People $v$. Barnes well represents this viewpoint. ${ }^{82}$ In that case a statute made it a misdemeanor to drive at the locus in quo at a rate of speed exceeding ten miles per hour. $D$, while driving at a greater rate than that permitted, killed $V$. The lower court took the position that if the jury found that $D$ drove at an unlawful rate of speed at the time the accident occurred, then $D$ was guilty of involuntary manslaughter because he had committed a homicide while doing an unlawful act. The Supreme Court of Michigan reversed the decision of the lower court. While ostensibly refusing "to split hairs" as to what kind of act is required by the common-law definition of involuntary manslaughter, the court states that "the mere running of an automobile upon a highway is not in itself unlawful", and that the rate of speed is only one of the elements bearing on the question of gross negligence. In State $v$. Horton, ${ }^{83}$ a statute made it a misdemeanor to 
hunt wild game on another's land without the owner's written permission. $D$ did so hunt on the land of another in violation of the statute, and killed $V$, a hunting companion, under the impression that he was shooting at a wild turkey. The jury found that $D$ was hunting in neither a dangerous nor negligent manner. The Supreme Court of North Carolina held that $D$ was not guilty of involuntary manslaughter on the ground that the unlawful act was only malum prohibitum, and therefore not sufficient to supply the requisite criminality. The lack of causal connection between the unlawful act and the homicide is so apparent that the entire discussion by the court of malum in se and malum prohibitum is not only superfluous, but also unwarranted. The decisions in other cases may be similarly criticized. ${ }^{84}$

Indeed, some courts which adhere to the distinction between an act malum in se and an act malum prohibitum have gone even farther than not requiring that the unlaw fulness of the act be the cause of the death. These courts at times fail even to give adequate effect to the fundamental requirement of the law that before any culpability can be said to attach to a defendant in a homicide case it must be clearly established that it was the defendant's act that caused the death.

Thus in State v. Reitze, ${ }^{85}$ a statute prohibited further sale of liquor to a person visibly under the influence of it. In violation of this statute, $D$ had sold some liquor to $V$ who shortly thereafter was killed when he fell from a wagon upon which he had tried to climb. $D$ was indicted for manslaughter. The court, emphasizing that the unlawful act was only malum prohibitum, reached the decision that $D$ was not guilty because $V$ 's death was not a natural or probable consequence of $D$ 's violation of the statute. In Keller $v$. State, ${ }^{86}$ the defendant drove while under the influence of intoxicants in violation of a statute, and killed $V$. $D$ sought to introduce evidence which, if admitted, would have proved that despite his drunkenness he drove as carefully as any reasonable and sober man would, and that the accident was caused by $V$ 's sudden and unexpected appearance in the middle of the street. The Supreme Court of Tennessee held that driving under the influence of liquor is an act malum in se, and that "Such being our view of the matter, we think

84. People v. Harris, 214 Mich. 145, 182 N. W. 673 (Ig2I) (in which the court required gross and culpable negligence which should be the proximate cause of the homicide); People v. Pavlic, 227 Mich. 562, I99 N. W. 373 (I924); Thiede v. State, 106 Neb. 48,182 N. W. 570 (I921) (wherein the court required an intent on the part of the defendant to commit a wrong against a person or his property, and in the absence of that, negligence "so as to manifest a reckless disregard" for the safety of others); Estell v. State, 5I N. J. L. 182, I7 Atl. II8 (1889); State v. De Fonti, 34 R. I. 5I, 82 Atl. 722 (IgI2) (in which there was an unlawful act, and sufficient connection of the nature of the cause and effect, yet the court insisted on negligence).

85. 86 N. J. L. 407,92 At1. 576 (I9I4).

86. I55 Tenn. 633,299 S. W. 803 (1927). 
the policy of the law forbids an investigation as to probable consequences". The court added further that $V$ 's conduct was not relevant either, since it was only contributory negligence which is not a defense in a criminal case. ${ }^{87}$

It is submitted that in both cases just referred to the decisive question ought to be whether the unlawful act-malum in se or malum prohibitum-may, in law, be said to be the cause of the death.

Quite aside from the grave oversight of the question of causation, the position which these courts have taken, namely, that an act malum prohibitum is no factor in involuntary manslaughter, whereas an act malum in se would be, is historically unsound. There is no authority in the common-law jurisprudence on the subject for such a broad proposition. Furthermore, it is incomprehensible that an offense made punishable by the legislature by fine or imprisonment should not be a sufficiently unlawful act. It would be better to abolish the species of involuntary homicide caused in the commission of an unlawful act altogether than to indulge in arbitrary quibbling as to which crimes on the statute books are sufficiently criminal and which are not. Indeed, after all the various definitions of the two kinds of "mala" are considered, one finds very meager guidance in formulating a concise principle on the subject. Statements of the type that driving while intoxicated is an act malum in se, and driving while merely under the influence of liquor is an act malum prohibitum, ${ }^{88}$ by no means help to eliminate the confusion. Some courts seem to proceed on the premise that the distinction lies in the circumstance of whether a given act is "absolutely" prohibited, or merely "qualifiedly" so; if the latter, it is a malum prohibitum because not obviously evil. Thus, in one case the court says, "the mere running of an automobile on a public highway is not in itself unlawful".89 In another case the court emphasizes the fact that the legislature has not absolutely prohibited the sale of liquor but has done so only under certain conditions in order to prove that the sale of liquor, even when in direct violation of the statute, is only malum prohibitum..$^{80}$

87. To the same effect see State v. Campbell, 82 Conn. 671, 74 Atl. 927 (I9ro); State v. Dugan, 84 N. J. L. 603, 89 Atl. 69I (I9I3). The first of these cases properly states the law that though contributory negligence, as such, is not a valid defense to an indictment for manslaughter, evidence of the victim's negligence should be admitted as relevant to the question of whether the defendant's negligence was the efficient or proximate cause of the victim's death. But compare Thiede v. State, 106 Neb. 48 , I82 N. W. 570 (I92I), where the court made the flat statement that contributory negligence is no defense to an indictment. On the question of contributory negligence as a defense see Regina v. Longbottom, 3 Cox C. C. 439 (1845) (held to be no defense); Regina v. Hutchinson, 9 Cox C. C. 555, 557 (1864) (dictum to same effect) ; Regina v. Birchall, 4 F. \& F. I087 (I866) (which held that since it is a good defense in a civil action, it is also a good defense to an indictment).

88. See State v. Budge, I26 Me. 223, 228, I37 At1. 244, 247 (I927).

89. People v. Barnes, I82 Mich. I79, I92, I48 N. W. 400, 405 (I914).

90. State v. Reitze, 86 N. J. L. 407,92 Atl. 576 (I9r4). 
It requires no particular acumen to discover the fallacy of this approach. There are extremely few, if any, acts which are absolutely criminal at common law. As far as the realm of statutory offenses is concerned, no one would seriously contend that an absolute prohibition by a legislature on sales of a certain article (taking a prohibition on sales of oleomargerine as an example) will render such a sale an act malum in se.

Some courts while logically regarding an offense mahum prohibitum as an unlawful act which is just as sufficient as an offense malum in se for the purpose of determining guilt for an unintentional homicide, take the view at the other extreme when they say that all the state has to prove in such cases is (a) the commission of the unlawful act by the defendant, and (b) a homicide caused by that physical act. These courts do not require the unlawfulness to be the cause of the homicide, with the unfortunate result that a defendant who has committed the act of killing someone unintentionally, may be convicted of manslaughter even though the evidence shows that the fatality would have occurred even in the absence of the circumstance which is declared by law to render the entire act unlawful. Thus, in Lauterbach $v$. State, ${ }^{91}$ after saying that the violation of the statute was negligence per se, the court goes on to say on the subject of causal relation, "one who is engaged in the performance of an unlaw ful act must take the criminal consequences of whatever happens to third persons as a result of that act", at the same time making the general statement that the victim's running in front of the defendant's automobile was only contributory negligence, and therefore no defense. The Texas court, likewise, seems to be of this opinion. In McDaniel $v$. State, ${ }^{92}$ that court held that a conviction of "negligent homicide" in the first degree is sustained by evidence that the victim's death was caused by the defendant while the latter was engaged in doing an unlawful act, to wit, driving an automobile while under the influence of liquor, and then added the very doubtful sentence, "as is also the possession and transportation of intoxicating liquor". Another case decided by the same court ${ }^{93}$ also suggests that if a homicide is caused by the defendant within the res geste of an unlawful act (a misdemeanor), the defendant is guilty of manslaughter irrespective of whether the unlawfulness of his conduct was, in a strict sense, the cause of the killing. In that case the facts were that $V$ made a murderous attack on $D$ whom he had found in the commission of adultery with his wife, and $D$, in proper self-defense, killed $V$. Adultery was a misdemeanor by the then existing law of Texas. On this state of facts

9I. 132 Tenn. 603, I79 S. W. I30 (I915).

92. ro5 Tex. Cr. App. 468, 288 S. W. I08I (1926).

93. Reed v. State, II Tex. Ct. App. 509 (I882). 
the court said that if to avenge the wrong, $V$ made a dangerous or murderous attack upon $D$, in resistance to which $D$ killed $V, D$ would be guilty of manslaughter, because he was committing a misdemeanor which was the cause of, and brought about the necessity for the homicide. ${ }^{94}$

This view, however, is only followed by a minority of the courts in this country. It is out of line with the well established principles as to causation in criminal cases and represents an undue extension of the law of criminal homicide. The whole doctrine of the aggravation of an accidental homicide by the doing of an unlawful act is an unfortunate one, and its application should be confined to cases where it is shown that the homicide would not have occurred but for the defendant's violation of the law, i. e., where the unlawful element of the intended offense caused the homicidal result.

Lastly there is a third group of jurisdictions which represents the middle ground between the two extreme positions previously discussed. In these jurisdictions an act malum prohibitum is considered a sufficiently unlaw ful act to make the actor responsible for the homicide, no negligence on the part of the defendant being required; but it is insisted that the unlawfulness, as distinguished from the mere physical act, should be the cause of the homicide. In Jackson $v$. State, ${ }^{95}$ the defendant was convicted of manslaughter for having killed $V$ while driving in excess of fifteen miles per hour. The Supreme Court of Ohio held that the failure of the lower court to instruct the jury on the point of proximate cause constituted a reversible error, and said that in order that $D$ be convicted, the jury must find that $D$ 's violation of the speed statute was the proximate cause of $V$ 's death. The court properly points out that if this element is omitted, $D$ would have been guilty even if $V$ fell in the path of the moving vehicle from a balloon while $D$ was proceeding at a rate slightly faster than the one allowed by the statute. "We are unable to comprehend", says the court, "the consistency of a rule which would justify the conviction of the surviving party where there could be no civil recovery . . . a man's liberty is no less precious

94. See Commonwealth v. Tole, 25 Dist. 957 ( $\mathrm{Pa}$. I9I5), where the court strongly intimates that if the homicide occurred while $D$ was doing any unlawful act, e. g., driving without a license, $D$ would be guilty of manslaughter. It is obvious that the homicide brought about under such circumstances cannot be said to be due to the fact that $D$ was not a licensed driver. In this connection see also People v. Halbert, $78 \mathrm{Cal}$. App. 598, 248 Pac. 969 (1926).

95. I0I Ohio St. 152, 127 N. E. 870 (1920). See also State v. Schaeffer, 96 Ohio St. 215, II7 N. E. 220 (1917). In Carbo v. State, 4 Ga. App. 583, 62 S. E. I40 (I908) (where $D$ kept certain explosives in his house in violation of a statute, and $V$, a fireman, walked in after having been apprised of the danger), the court justly said, "There can be no conviction of the offense of involuntary manslaughter, either in the commission of an unlawful act, or in the commission of a lawful act without due caution and circumspection, where the homicide is directly due to an independent, intervening cause in which the accused did not participate and which he could not foresee." See also State v. McIvor, 3I Del. I23, III Atl. 6I6 (Ct. Oyer and Ter. I920). 
than his property". In another well-considered case the court said, "to convict of manslaughter for killing a person while in the commission of an unlawful act, the state must show more than a mere coincidence of time and place between the wrongful act and the death. . . . It must show that the unlaw ful act was the proximate cause of the killing". ${ }^{96}$

Some cases of this class go even farther and require not only a relationship of cause and effect between the unlawfulness of the defendant's conduct and the homicide, but also that the latter be the natural and probable consequence of the former. In Votre $v$. State, ${ }^{97} \mathrm{D}$ gave whiskey to $V$, a minor, contrary to a statute. The alcohol caused $V$ to suffer a heart attack of which he died. The court held that $D$ was not guilty, stating that in order that there be a conviction, the homicide must follow both as a concomitant part of the perpetration of, or attempt to commit the unlawful act, and as a natural and probable result thereof.98 Inasmuch as cases of this class emphasize the necessity for a reasonable contemplation of death to another from the doing of the unlawful act, they represent a radical departure from hitherto well-established law which regards the test of natural and probable consequences in homicide cases as a method by which the jury may infer from the evidence either (a) the presence or absence of intent to cause death, or (b) the existence or non-existence of negligence. Thus defined, the application of this test is in no way dependent upon the lawfulness or unlawfulness of the defendant's act.

To hold that a defendant may not legally be convicted for an unintended homicide committed while the defendant was engaged in the perpetration of some unlawful act unless the jury find that as a reasonable man he should have contemplated that the death of some person might result from his act, would be tantamount to a total nullification of the legal effect of the unlawful act in the definition of this common-law offense.

96. State v. Mulcahy, 3I8 I11. 332, I49 N. E. 266 (I925). In that case a policeman accidentally killed a friend of his. The state sought to predicate his guilt for the homicide on the ground that at that time the policeman failed to arrest certain people engaged in gambling in his presence.

97. I92 Ind. 684, r38 N. E. 257 (I923).

98. Kimmel v. State, I98 Ind. 444, I54 N. E. I6 (I926). Natural and probable consequences are also considered a factor in Commonwealth v. Couch, $32 \mathrm{Ky}$. L. Rep. 638 , 106 S. W. 830 , I6 I. R. A. (N. S.) 327 (1908) (case of unlawful stirring up of fright). In People v. Crenshaw, 298 Iil. $4 \mathrm{I2}$, I3I N. E. 576 (r92I), the court decided that in order for an unintended homicide in the commission of an unlawful act to be manslaughter, the killing must result as a natural and probable consequence of the doing of the unlawful act. The case of Black v. State, 103 Ohio St. 434, I33 N. E. 795 (I92I), is to the effect that unlawful killing, as used in manslaughter, must be such as would naturally, logically and proximately result from the commission of some unlawful act as defined by statute, and such unlawful act must be one that would be reasonably anticipated by an ordinarily prudent person as likely to result in such killing. In Gainer v. State, I00 Fla. I64, I24 So. 576 (1930), the court reached an opposite conclusion, holding that since intent to kill is not an element in manslaughter, the question of reasonable and probable consequences does not arise. 